\title{
Transgender Corneal Donors: A Dilemma Worthy of Attention
}

Majid Moshirfar - Tanner W. Brown · Jackson L. Goldberg •

William D. Wagner · Yasmyne C. Ronquillo

Received: July 25, 2018 / Published online: September 26, 2018

(C) The Author(s) 2018

\section{ABSTRACT}

Currently, there are no specific guidelines in place to direct eye banks on how to deal with donated tissue from transgender individuals. This commentary will examine the history of corneal transplantation and the importance of the corneal tissue donor. In doing so, the donor selection criteria established by the Food and Drug Administration will be presented. Additionally, the history of blood donor deferral policies created for men who have sex with men and how those policies have changed over time

Enhanced digital features To view enhanced digital features for this article go to https://doi.org/10.6084/ m9.figshare.7076714.

M. Moshirfar $(\bowtie) \cdot$ Y. C. Ronquillo

HDR Research Center, Hoopes Vision, Draper, UT, USA

e-mail: cornea2020@me.com

M. Moshirfar

Department of Ophthalmology and Visual Sciences, John A. Moran Eye Center, University of Utah

School of Medicine, Salt Lake City, UT, USA

M. Moshirfar

Utah Lions Eye Bank, Murray, UT, USA

T. W. Brown · J. L. Goldberg

The University of Texas Health Science Center at

Houston School of Medicine, Houston, TX, USA

W. D. Wagner

Virginia Commonwealth University School of

Medicine, Richmond, VA, USA will be explored. We provide an evidence-based framework for potential guidelines regarding the transgender population and eye tissue donation.

Keywords: Blood donation; Cornea donation; Corneal transplant; Eye bank; LGBTQ; MSM; Transgender

\section{COMMENTARY}

Since Eduard Zirm performed the first successful corneal transplant in 1905 [1], there have been significant advancements made in surgical technique, technology, and postoperative care. Selective lamellar keratoplasty, the femtosecond laser, and modern pharmacology have revolutionized the procedure, allowing for greater precision and improved outcomes [2, 3]. A modern corneal transplant surgery looks markedly different than the one performed over 100 years ago. Despite these improvements, the global benefits from ocular tissue transplantation will continue to be limited by supply, the common frustration of all organ transplantation fields. Until the bioengineering of effective, safe, and cost-efficient alternatives, the ocular tissue donor remains an invaluable resource for the treatment of worldwide ocular pathology [4].

The current guidelines put forth by the Food and Drug Administration (FDA) and the Eye 
Bank Association of America (EBAA) for determining the eligibility of eye tissue donors are judiciously extensive and thorough. They call for a stepwise approach to screening and testing to ensure both recipient safety and cost-effectiveness of the donation process. Donor screening includes, at minimum, a physical examination, review of available health records, tissue evaluation, and detailed medical and social history $[5,6]$. The process gives special focus to conditions that would lead to poor outcomes for the recipient. After initial screening, donors are tested for various communicable diseases including human immunodeficiency virus (HIV) types 1 and 2, hepatitis $B$, hepatitis $\mathrm{C}$, and syphilis [5]. These tests result in objective data that can easily be interpreted and used to clearly guide judgement on the eligibility of a donor. As an example, a donor who tests reactive using an FDA-licensed HIV-1 serology or nucleic acid test (NAT) will be automatically deemed ineligible [5]. However, other aspects of the screening process, the review of social history in particular, is far more subjective and is difficult to directly relate to recipient outcomes.

Aside from diagnosable communicable diseases, the screening process focuses on aspects of donors' medical and social history that may serve as risk factors for such conditions. The EBAA has compiled a list of behaviors that will deem an ocular tissue donor ineligible, including: "men who have had sex with another man in preceding 5 years", "persons who have injected drugs for a non-medical reason in preceding 5 years", and "persons who have engaged in sex in exchange for money or drugs in preceding 5 years" [5]. Deferral for these behaviors is based on the idea that they increase a donor's risk of having a communicable disease such as HIV, hepatitis B, and hepatitis C, which can be transmitted to a recipient. Indeed, it is true that in the USA the prevalence of these diseases appears to be higher in the aforementioned categories than in the general population; for example, men who have sex with men accounted for $67 \%$ of all HIV diagnoses, and $83 \%$ of diagnoses among men in 2016 [7, 8]. However, perspectives on sexuality, sexual orientation, and gender are evolving. As society becomes more inclusive and overcomes previously held biases, the medical field must be held responsible for adapting to the changing demographics of the populations they serve. Discriminating against organ donors with minority sexual orientations and gender identities unnecessarily constricts the donor pool.

Because of the novelty of societal acceptance, transgender people are now potential organ donors. Should special consideration be taken for a donor identification as transgender? Unfortunately, the FDA and EBAA do not provide specific guidelines regarding the ability of transgender persons to serve as ocular tissue donors, leaving room for the infiltration of unscientific personal biases. Because misunderstandings still exist about the transgender population, feasible donations can be rejected because of the lack of official guidance. The only explicit consideration of this population came from the Revised Recommendations for Reducing the Risk of Human Immunodeficiency Virus Transmission by Blood and Blood Products-Guidance for Industry, which concluded that male or female gender will be self-identified [9].

Before further discussion, it is important to understand the terminology used and preferred by the transgender population in order to recognize the potential challenges facing current guidelines and the consequent need for new, linguistically clear guidelines for transgender donors. Table 1 presents common terms and definitions provided by GLAAD, an organization that works to promote LGBTQ acceptance [10].

Presently, deferral decisions for transgender individuals are largely based on risk factors like the ones mentioned above. However, the language used by the definitive FDA and EBAA can be difficult to apply to the transgender population who do not use traditional gender selfidentification, and who may have, at different points in their lives, been considered different genders. As an example, would a transgender woman who only had sex with men after her transition be considered a man who has (had) sex with men, and subsequently deferred? What about a transgender man that had sex with a man before his transition? Because these guidelines do not specifically account for individuals who may have a different gender 
Table 1 Common terminology

\begin{tabular}{|c|c|}
\hline Term & Definition \\
\hline $\begin{array}{l}\text { Gender } \\
\text { identity }\end{array}$ & $\begin{array}{l}\text { A person's internal, deeply held sense of } \\
\text { their own gender, which may or may } \\
\text { not match the sex they were assigned at } \\
\text { birth }\end{array}$ \\
\hline Sex & $\begin{array}{l}\text { The classification of a person as male or } \\
\text { female typically based on external } \\
\text { anatomy present at birth }\end{array}$ \\
\hline Transgender & $\begin{array}{l}\text { An umbrella term for people whose } \\
\text { gender identity and/or expression is } \\
\text { different from the sex they were } \\
\text { assigned at birth }\end{array}$ \\
\hline $\begin{array}{l}\text { Transgender } \\
\text { man }\end{array}$ & $\begin{array}{l}\text { Person who was assigned female sex at } \\
\text { birth but identifies as a man }\end{array}$ \\
\hline $\begin{array}{l}\text { Transgender } \\
\text { woman }\end{array}$ & $\begin{array}{l}\text { Person who was assigned male sex at birth } \\
\text { but identifies as a woman }\end{array}$ \\
\hline Transition & $\begin{array}{l}\text { A complex process that occurs over a long } \\
\text { period of time in which one alters one's } \\
\text { birth sex. May vary from person to } \\
\text { person }\end{array}$ \\
\hline $\begin{array}{l}\text { Sexual } \\
\text { orientation }\end{array}$ & $\begin{array}{l}\text { Distinct from identity, describes a } \\
\text { person's physical, romantic, and/or } \\
\text { emotional attraction to another person }\end{array}$ \\
\hline Queer & $\begin{array}{l}\text { An adjective used by some people whose } \\
\text { sexual orientation is not exclusively } \\
\text { heterosexual }\end{array}$ \\
\hline Cross-dresser & $\begin{array}{l}\text { Typically used to refer to heterosexual } \\
\text { men who occasionally wear clothes, } \\
\text { make-up, and accessories culturally } \\
\text { associated with women. Preferred over } \\
\text { the term "transvestite" }\end{array}$ \\
\hline
\end{tabular}

identity than their gender assigned at birth, it becomes difficult to reliably characterize their risk factors.

When attempting to develop recommendations, it is important to review the history of how these recommendations came to be and how they have changed. The literature on ocular tissue donation deferral policy based on sexual behavior is sparse, so blood donation will be used as a model. The first ban on blood donations from men who had sex with men in the USA was established in 1985 and was indefinite. The driving force behind this ban was the outbreak of HIV infections among specific populations in the 1970s and 1980s (including men who have sex with men, IV drug users, and hemophiliacs receiving frequent clotting factor injections) in conjunction with the uncertainty in the cause of these outbreaks and unavailability of effective screening tests [11]. This indefinite ban existed, despite increasing knowledge about the infection and advancements in testing, until 2015 when the FDA changed it to a 1-year deferral [9]. This meant that a man would not be immediately banned from donating blood if his last sexual encounter with another male was over a year ago. Although this is a step in the right direction, a deferral period of 1 year is inconsistent with the ability of screening tests to detect HIV and other communicable diseases.

With the increasing (approaching 100\% [12]) sensitivity of screening tests for HIV, the idea of a deferral time only makes sense when considering the window period-the time between first infection and when that infection is detectable in tests [13]. With modern screening tests using NAT, the window period can be as little as 6 days for HIV, 22 days for hepatitis B, and 5 days for hepatitis $C$ [14]. This information would suggest that the appropriate deferral time for any behavior that is considered high risk for these diseases should be much less than a year. Some countries around the world have modernized their blood donation policies for classically high-risk populations. Both Spain and Italy have abandoned specific bans, electing to use a system of individual risk assessment in lieu of blanket deferrals based on orientation [15]. While this system is not without its drawbacks, the most obvious of which is the inaccurate nature of social history screening, we believe it takes more relevant information into account and avoids inequitable treatment of a classically marginalized group of people.

Although donor questionnaires and social history can be unreliable sources, it is important 
to note that they are helpful in certain situations. The real problem is the seemingly arbitrary designation of 1 year as an appropriate period of deferral. Is a person who engaged in high-risk behavior 9 months prior really at a higher risk of having an undetected infection than a person who engaged in similar behavior 13 months prior? The sensitivities of our screening tests would suggest not.

Keeping in mind the unreliability of social history, the ability of screening tests to detect infections, and the shifting social attitudes towards gender, we are suggesting that the following be used as a framework for future guidelines regarding the eligibility of transgender individuals to serve as ocular tissue donors: initial identification information will include options for "transgender man", "transgender woman", and "other". The blood donation policies of Spain and Italy will be modeled and there will be no automatic deferral period for the transgender population, but instead individual risk assessment will be used. All transgender ocular tissue donors will be tested for communicable diseases using a combination of NAT and serology testing. Transgender men and women will be deferred for 3 months from last reported episode of high-risk sexual behavior. Three months ensures that newly acquired infections will be adequately detected. High-risk behaviors include sex with multiple partners, sex in exchange for money or drugs, or sex outside of a monogamous relationship with either a transgender man, woman, or a man who has sex with men. These sexual behaviors are determined to be high risk because data suggests that these populations have a relatively high prevalence of HIV [8, 16, 17]. Currently, there is little data available on the prevalence of other communicable disease such as hepatitis $B$ and hepatitis $C$ in the transgender population in the USA. However, a study in Italy found that the rates of these diseases among transgender individuals seeking reassignment surgery were similar to that reported in the general population [18].

A unique feature of the transgender population is the use of long-term hormone replacement therapy. Many transgender individuals make the decision to use hormone therapy as a means to either masculinize or feminize their physical appearance. Transgender males will typically use androgens such as testosterone, while transgender women typically use a combination of estrogens and anti-androgens [19]. Because it would seem that an increasing number of transgender individuals are choosing to use hormone replacement therapy [20], the possible effects that this therapy may have on donor tissue, and subsequently on the recipient, should not be overlooked and require more research.

We realize that transgender individuals make up only $0.6 \%$ (1.4 million) of the US population [21]; however, with respect to ocular tissue donation, any possible donor needs to have proper consideration. According to the Global Survey of Corneal Transplantation and Eye Banking, there are an estimated 10 million people worldwide with bilateral corneal blindness, making it the third leading cause of blindness behind cataract and glaucoma. This survey also estimates that there are 12.7 million people currently waiting for a corneal transplantation [4]. This deficit is especially unacceptable when considering not only the social impact of blindness but also the economic burden it imposes on an individual and their community. Cost-benefit analysis with respect to corneal transplantation has found that blindness is extremely expensive when the medical costs and years of lost productivity are taken into account [22]. Because of the significance of every eye tissue donor, it is important for there to exist clear, evidence-based guidelines to direct the eligibility of transgender donors. It is time the USA move away from outdated deferral policies which unfairly stigmatize certain groups and towards a system that will ensure the maximum number of high-quality tissue donations.

\section{ACKNOWLEDGEMENTS}

Funding. This study was funded by an unrestricted grant from Research to Prevent Blindness (RPB), New York, NY. The article processing charges were funded by the authors.

Authorship. All named authors meet the International Committee of Medical Journal 
Editors (ICMJE) criteria for authorship for this article, take responsibility for the integrity of the work as a whole, and have given their approval for this version to be published.

Disclosures. Majid Moshirfar, Tanner W. Brown, Jackson L. Goldberg, William D. Wagner, and Yasmyne C. Ronquillo have nothing to disclose.

Compliance with Ethics Guidelines. This article does not contain any studies with human participants or animals performed by any of the authors.

Data Availability. Data sharing is not applicable to this article as no datasets were generated or analyzed during the current study.

Open Access. This article is distributed under the terms of the Creative Commons Attribution-NonCommercial 4.0 International License (http://creativecommons.org/licenses/ by-nc/4.0/), which permits any noncommercial use, distribution, and reproduction in any medium, provided you give appropriate credit to the original author(s) and the source, provide a link to the Creative Commons license, and indicate if changes were made.

\section{REFERENCES}

1. Crawford AZ, Patel DV, McGhee CN. A brief history of corneal transplantation: from ancient to modern. Oman J Ophthalmol. 2013;6(Suppl 1):S12-7.

2. Tan DT, Dart JK, Holland EJ, Kinoshita S. Corneal transplantation. Lancet. 2012;379(9827):1749-61.

3. Nguyen NX, Seitz B, Martus P, Langenbucher A, Cursiefen C. Long-term topical steroid treatment improves graft survival following normal-risk penetrating keratoplasty. Am J Ophthalmol. 2007;144(2):318-9.

4. Jullienne R, He Z, Aldossary M, et al. Global survey of corneal transplantation and eye banking. JAMA Ophthalmol. 2016;134(2):167-73.

5. EBAA. Medical standards. Int $\mathrm{J}$ Eye Bank. 2016;4(3):1-35.
6. FDA. Guidance for industry: eligibility determination for donors of human cells, tissues, and cellular and tissue-based products (HCT/Ps). 2007. https:// www.fda.gov/downloads/biologicsbloodvaccines/ guidancecomplianceregulatoryinformation/guidan ces/tissue/ucm091345.pdf. Accessed 13 July 2018.

7. Frieden TR, Harold Jaffe DW, Thacker SB, et al. Integrated prevention services for HIV infection, viral hepatitis, sexually transmitted diseases, and tuberculosis for persons who use drugs illicitly: summary guidance from CDC and the U.S. Department of Health and Human Services Morbidity and Mortality Weekly Report Recommendations and Reports Centers for Disease Control and Prevention MMWR Editorial and Production Staff MMWR Editorial Board. http://www.cdc.gov/ mmwr/cme/conted.html. Accessed 19 July 2018.

8. Centers for Disease Control and Prevention (CDC). Diagnoses of HIV infection in the united states and dependent areas, 2016. HIV Surveill Rep. 2016;28(28).

9. FDA. Revised recommendations for reducing the risk of human immunodeficiency virus transmission by blood and blood products: guidance for industry. 2015. pp. 1-27. http://www.fda.gov/ BiologicsBloodVaccines/GuidanceComplianceRegu latoryInformation/Guidances/default.htm. Accessed 8 July 2018.

10. GLAAD. GLAAD media reference guide, 10th edition. 2016. http://www.glaad.org/sites/default/files/ GLAAD-Media-Reference-Guide-Tenth-Edition.pdf. Accessed 9 July 2018.

11. Sacks CA, Goldstein RH, Walensky RP. Rethinking the ban-the U.S. blood supply and men who have sex with men. N Engl J Med. 2017;376(2):174-7.

12. Vargo J, Smith K, Knott C, et al. Clinical specificity and sensitivity of a blood screening assay for detection of HIV-1 and HCV RNA. Transfusion. 2002;42(7):876-85. https://doi.org/10.1046/j.15372995.2002.00130.x.

13. Kucirka LM, Sarathy H, Wolf JH, et al. Risk of window period HIV infection in high infectious risk donors: systematic review and meta-analysis. Am J Transplant. 2011;11(6):1176-87.

14. Humar A, Morris M, Blumberg E, et al. Nucleic acid testing (NAT) of organ donors: is the 'best' test the right test? A consensus conference report. Am J Transplant. 2010;10(4):889-99. https://doi.org/10. 1111/j.1600-6143.2009.02992.x.

15. Brailsford SR, Kelly D, Kohli H, Slowther A, Watkins NA. Who should donate blood? Policy decisions on donor deferral criteria should protect recipients and 
be fair to donors. Transfus Med. 2015;25(4):234-8. https://doi.org/10.1111/tme.12225.

16. Clark H, Babu AS, Wiewel EW, Opoku J, Crepaz N. Diagnosed HIV infection in transgender adults and adolescents: results from the national HIV surveillance system, 2009-2014. AIDS Behav. 2017;21(9):2774-83.

17. Stephens SC, Bernstein KT, Philip SS. Male to female and female to male transgender persons have different sexual risk behaviors yet similar rates of STDs and HIV. AIDS Behav. 2011;15(3):683-6. https://doi.org/10.1007/s10461-010-9773-1.

18. Luzzati R, Zatta M, Pavan N, et al. Prevalence of human immunodeficiency virus, hepatitis $\mathrm{B}$ virus, and hepatitis $C$ virus infections among transgender persons referred to an Italian center for total sex reassignment surgery. Sex Transm Dis. 2016;43(7): 407-11.
19. Unger CA. Hormone therapy for transgender patients. Transl Androl Urol. 2016;5(6):877-84.

20. Leinung M, Urizar M, Patel N, Sood S. Endocrine treatment of transsexual persons: extensive personal experience. Endocr Pract. 2013;19(4):644-50. https://doi.org/10.4158/EP12170.OR.

21. Flores AR, Herman JL, Gates GJ, Brown TNT. How many adults identify as transgender in the United States? The Williams Institue. 2016. pp 1-13. http:// williamsinstitute.law.ucla.edu/wp-content/uploads /How-Many-Adults-Identify-as-Transgender-in-theUnited-States.pdf. Accessed 8 July 2018.

22. The Lewin Group I. Cost-benefit analysis of corneal transplant. 2013. http://restoresight.org/wp-con tent/uploads/2014/03/Lewin-Study-Sept-2013.pdf. Accessed 9 July 2018. 